\title{
Evaluation of Antioxidant Activity of Some Selected Tropical Fruits in South Kalimantan, Indonesia
}

Efrilia Tanjung ${ }^{1}$, Muhammad Hafidz MS ${ }^{2}$, Iskandar Thalib², Eko Suhartono ${ }^{3 *}$

${ }^{1}$ Datuk Sanggul General Hospital, South Kalimantan, Indonesia

${ }^{2}$ Research Unit Mutiara Bunda Mother and Child Hospital, South Kalimantan, Indonesia

${ }^{3}$ Medical Chemistry and Biochemistry Department, School of Medicine, Lambung Mangkurat of University,

South Kalimantan, Indonesia

\begin{abstract}
In the present study antioxidant and antioxidant activity of some tropical fruits was evaluated. Antioxidants are compounds or molecules that can scavenging and prevent free radicals and reactive oxygen species that can caused a cell damage. Fruit was known as a source of antioxidant. South Kalimantan Indonesia, has a variety of fruit such as mentega, nangka, timun suri and kuranji. Study for evaluating the antioxidant levels and activity of those fruit were never been investigated. Thus, our study aim to measure the antioxidant levels and antioxidant activtity of those selected fruits. Ascorbic acid, lycopene, $\beta$-carotene levels and antioxidant activity of four selected tropical fruits was evaluated using spectrophotometer. The result of this studied suggest that the four selected tropical fruits is potential antioxidant because it contained ascorbic acid, $\beta$-carotene, lycopene and had effect of scavenging radical hydroxyl, hydrogen peroxide and chellating ferrous iron.
\end{abstract}

Keywords: antioxidant activity, ascorbic acid, $\beta$-carotene, lycopene

\section{INTRODUCTION}

Fruits are source of antioxidants that are beneficial to health because it contains ascorbic acid, $\beta$-carotene, lycopene, and others that can scavenging the free radical $[1,2]$. Free radicals are atoms or molecules containing unpaired electrons therefore unstable molecule. It can react with the cell membrane biomolecules such as lipids, proteins, and carbohydrates. Because of that, the presence of antioxidants is necessary to prevent or delay the damage $[3,4]$.

Antioxidants are compounds or molecules that can scavenging and prevent free radicals and reactive oxygen species generated from the metabolism [4]. Plants and animals maintain complex systems of multiple types of antioxidants, such as glutathione, vitamin C, vitamin $A$, and vitamin $E$ as well as enzymes such as peroxydase, catalase, superoxide dismutase and others. Insufficient levels of antioxidants, or inhibition of the antioxidant enzymes, cause oxidative stress and may damage or kill cells [5].

\footnotetext{
${ }^{*}$ Corresponding author:

Eko Suhartono

Faculty of Medicine, University of Lambung Mangkurat,

Banjarmasin, Indonesia

E-mail: ekoantioxidant@gmail.com
}

In South Kalimantan Indonesia is a tropical country that has a variety of fruits that are consumed for food and health [6]. For example methanol exctract timun suri (Cucumis sativus) can be useful as an antiinflammatory, analgesic, and antioxidants [7, 8]. Nangka (Artocarpus heterolphyllus) can be useful as anti-bacterial, anti-diabetic, anti-inflammatory, antioxidant and anti-helmintics [9]. Mentega (Diospyros blancoi) can be useful as anti-diarrhea and antioxidant [10].

The antioxidant properties mechanism of fruits through the inhibiting initiation and breaking chain propagation or suppressing formation of ROS by binding to the metal ions, reducing hydrogen peroxide, and quenching superoxide and singlet oxygen [5]. The antioxidant activity of those fruits have not been investigated, therefore, many study should be performed. In this present study, we investigate ascorbic acid, $\beta$ carotene, lycopene and antioxidant activity of kuranji, mentega, timun suri, and nangka.

\section{MATERIALS AND METHODS \\ Chemical and Materials}

1\% metaphosphoric acid, 2,6-dichloro phenolindophenol, acetone-hexane, $1 \mathrm{mM} \mathrm{FeCl} 3,2 \mathrm{mM} \mathrm{FeCl}$, 
$1 \mathrm{mM}$ ortophenanthroline, $0.2 \mathrm{M}$ phosphate buffer ( $\mathrm{pH}$ 7.8), $0.17 \mathrm{M} \mathrm{H} 2 \mathrm{O} 2, \mathrm{NaNO} 2$, and $\mathrm{AlCl}_{3}$ were from Sigma.

\section{Fruit Materials}

Four types of tropical fruits and used as reference were studied. They were kuranji (Dialium indum L), mentega (Diospyros blancoi), timun suri (Cucumis sativus), and nangka (Artrocarpus heterolphyllus).

\section{Ascorbic Acid Content}

Ascorbic acid was determined according to the method of Klein and Perry (1982). The dried methanolic extract $(100 \mathrm{mg}$ ) was extracted with $10 \mathrm{ml}$ of $1 \%$ metaphosphoric acid for 45 minute at room temperature and filtered through whatman no. 4 filter paper. The filtrate $(1 \mathrm{ml})$ was mixed with $9 \mathrm{ml}$ of 2,6dichlorophenolindophenol and the absorbance was measured within $30 \mathrm{~min}$ at $515 \mathrm{~nm}$ against a blank. Content of ascorbic acid was calculated on the basis of the calibration curve of authentic L-ascorbic acid ( 0.020 $-0.12 \mathrm{mg} / \mathrm{ml}$ ). The assays were carried out in triplicate; the results were mean values \pm standard deviations and expressed as mg of ascorbic acid/g of extract [11].

\section{$\beta$-Carotene and Lycopene Content}

$\beta$-Carotene and lycopene were determined according to the method of Nagata and Yamashita (1992). The dried methanolic extract $(100 \mathrm{mg})$ was vigorously shaken with $10 \mathrm{ml}$ of acetone-hexane mixture (4:6) for $1 \mathrm{~min}$ and filtered through whatman no. 4 filter paper. The absorbance of the filtrate was measured at 453, 505, 645 and $663 \mathrm{~nm}$. Contents of $\beta-$ carotene and lycopene were calculated according to the following equations: lycopene $(\mathrm{mg} / 100 \mathrm{ml})=-0.0458$ $\mathrm{A} 663+0.372$ A505-0.0806 A453; $\beta$-carotene $(\mathrm{mg} / 100$ $\mathrm{ml})=0.216$ A663- 0.304 A505+ 0.452 A453. The assays were carried out in triplicate; the results were mean values \pm standard deviations and expressed as $\mathrm{mg}$ of carotenoid/g of extract [11].

\section{Hydroxyl Radical Scavenging Activity}

The scavenging activity for hydroxyl radicals was measured with Fenton reaction [12]. The absorbance of the mixture at $560 \mathrm{~nm}$ was measured with a spectrophotometer. Hydroxyl radical scavenging activity was calculated using the equation: (1absorbance of sample/ absorbance of control) $\times 100$. Each experiment was carried out in triplicate and results averaged expressed as mean $\pm \mathrm{SD}$.

\section{Chellating Effect of Ferrous Iron}

The chelating effect of ferrous ions was estimated by the method of Hung-Ju Chou et al. [13]. The absorbance of the mixture was measured at $562 \mathrm{~nm}$. Chelating effect was calculated using the equation: ( 1 absorbance of sample/ absorbance of control) $\times 100$. Each experiment was carried out in triplicate and results averaged expressed as mean $\pm \mathrm{SD}$.

\section{Hydrogen Peroxide Scavenging Activity}

The hydrogen peroxide scavenging was determined according to the method of Ruch et al. [14]. The absorbance value of the reaction mixture was recorded at $230 \mathrm{~nm}$. Hydrogen peroxide scavenging activity was calculated using the equation: ( 1 - absorbance of sample/ absorbance of control) $\times 100$. Each experiment was carried out in triplicateand results averaged expressed as mean $\pm \mathrm{SD}$.

\section{RESULTS AND DISCUSSION Ascorbic Acid}

Ascorbic acid is known as vitamin $\mathrm{C}$ is a substance commonly found in fruits [13-14]. Some studies suggest that the consumption of fruits and vegetables are associated with reduced risks of diseases [15]. Elderly people who take vitamin $\mathrm{C}$ and vitamin $\mathrm{E}$ supplements have a $50 \%$ lower risk of dying prematurely from disease than do people who do not supplement A Californian study has concluded people who consume more than $750 \mathrm{mg} / \mathrm{d}$ of vitamin $\mathrm{C}$

Table 1. Ascorbic Acid, $\beta$-Carotene and Lycopene of Four Selected Fruits

\begin{tabular}{ccccc}
\hline \hline Local Name & Scientific Name & $\begin{array}{c}\text { Ascorbic Acid } \\
(\mathrm{mg} / 100 \mathrm{mg})\end{array}$ & $\begin{array}{c}\text { B-Carotene } \\
(\mathrm{mg} / 100 \mathrm{ml})\end{array}$ & $\begin{array}{c}\text { Lycopene } \\
(\mathrm{mg} / 100 \mathrm{ml})\end{array}$ \\
\hline Mentega & Diospyros blancoi & $1.320 \pm 0.010$ & $0.196 \pm 0.010$ & $0.333 \pm 0.012$ \\
Kuranji & Dialium indum L & $0.176 \pm 0.012$ & $0.128 \pm 0.013$ & $0.016 \pm 0.001$ \\
Timun Suri & Cucumis Sativus & $0.352 \pm 0.011$ & $0.125 \pm 0.012$ & $0.010 \pm 0.002$ \\
Nangka & Artocarpus & $0.440 \pm 0.012$ & & \\
& heterolphyllus & & $0.192 \pm 0.021$ & $0.072 \pm 0.001$ \\
\hline \hline
\end{tabular}


reduce their risk of dying prematurely by $60 \%$ [15].

The result of ascorbic acid levels is shown in table 1. All four selected fruits contains ascorbic acid, and mentega had a highest levels of ascorbic acid followed by jackfruit, timun suri and kuranji. The levels of ascorbic acid showed that the four selected fruits has a potential antioxidant activity.

Ascorbic Acid is a water-soluble antioxidant. It was first isolated in 1928, by the Hungarian biochemist and nobel prize winner Szent-GyorGyi. It is an unstable, easily oxidized acid and can be destroyed by oxygen, alkali and high temperature [16].

Ascorbic acid has been shown to play important role in several physiological processes in plants and fruits, including growth, differentiation, and metabolism [17]. Body requires ascorbic acid for normal physiological functions. It helps in the metabolism of tyrosine, folic acid and tryptophan. It helps to lower blood cholesterol and contributes to the synthesis of the amino acids carnitine and catecholamine that regulate nervous system. It is needed for tissue growth and wound healing. It helps in the formation of neurotransmitters and increases the absorption of iron in the gut. Being an antioxidant, it protects the body from the harmful effects of free radicals and pollutants [16].

Since ascorbic acid is water soluble, it can work both inside and outside the cells to combat free radical damages. Free radicals seek out an electron pair to regain their stability. Ascorbic acid is an excellent source of electrons therefore it can donate electrons to free that radicals such as hydroxyl and superoxide radicals and quench their reactivity [16].

Ascorbic acid prevents free radical damage in the lungs and may even help to protect the central nervous
High doses given after but not before the injury successfully suppressed preventing edema [16].

\section{$\beta$ - Carotene and Lycopene}

Carotenoids, such as lycopene and $\beta$-carotene, are natural constituents of many plants and may protect against disease. Carotenoids are a family of pigmented compounds that are synthesized by plants and microorganisms but not animals. In plants, they contribute to the photosynthetic machinery and protect them against photo-damage [18].

Fruits and vegetables constitute the major sources of carotenoid in human diet. They are present as micro-components in fruits and vegetables and are responsible for their yellow, orange and red colors. Carotenoids are thought to be responsible for the beneficial properties of fruits and vegetables in preventing human diseases including cardiovascular diseases, cancer and other chronic diseases [18].

In recent years the antioxidant properties of carotenoids has been the major focus of research. More than 600 carotenoids have so far been identified in nature. However, only about 40 are present in a typical human diet. Of these 40 about 20 carotenoids have been identified in human blood and tissues. Close to $90 \%$ of the carotenoids in the diet and human body is represented by $\beta$-carotene, $\alpha$-carotene, lycopene, lutein and cryptoxanthin [18].

The levels of $\beta$-carotene and lycopene in four selected fruits shown in table 1 . The levels of $\beta$ carotene decreased in the order of mentega fruit > jackfruit > kuranji > timun suri, and the levels of lycopene decreased in the order of mentega fruit > jackfruit $>$ kuranji $>$ timun suri.

$\beta$-carotene is commonly known as a radical

Table 2. Antioxidant Activity of Four Selected Fruits

\begin{tabular}{cccc}
\hline \hline & $\begin{array}{c}\text { \% Scavenging } \\
\text { Hidroksil }\end{array}$ & $\begin{array}{c}\text { \% Chelating Ferrous } \\
\text { iron }\end{array}$ & $\begin{array}{c}\text { \% Scavenging } \\
\mathrm{H}_{2} \mathrm{O}_{2}\end{array}$ \\
\hline Mruits & $42.432 \pm 1.120$ & $28.191 \pm 0.910$ & $25.871 \pm 1.673$ \\
Kuntega & $45.918 \pm 2.211$ & $15.426 \pm 1.110$ & $24.378 \pm 1.721$ \\
Timun Suri & $40.893 \pm 1.212$ & $14.894 \pm 1.817$ & $26.866 \pm 1.523$ \\
Nangka & $36.623 \pm 1.124$ & $7.979 \pm 1.213$ & $12.438 \pm 2.170$ \\
\hline \hline
\end{tabular}

system problems from such damage. In a study of guinea pigs, pretreatment of ascorbic acid including effectively diminished the acute lung damage caused by the introduction of super oxide anion free oxygen radicals to the trachea. Ascorbic acid also has been tested as an antioxidant inflammatory reaction in mice. scavenger and a physical scavenger of singlet oxygen and is believed to play an important role in the inhibition of initial stages of lipid peroxidation [21]. The antioxidant properties of $\beta$-carotene have been suggested as being the main mechanism by which they afford their beneficial effects. Recent studies are also 
showing that carotenoids may mediate their effects via other mechanisms such as gap junction communication, cell growth regulation, modulating gene expression, immune response and as modulators of phase I and II drug metabolizing enzymes. However, carotenoids such as $\alpha$ - and $\beta$-carotene and $\beta$ cryptoxanthin have the added advantage of being able to be converted to Vitamin A and its related role in the development and disease prevention [18].

Several in vitro, animal and human experiments have demonstrated the antioxidant properties of carotenoids such as $\beta$-carotene. It is interesting to observe that $\beta$-carotene has also been reported to act as a pro-oxidant under certain situations. $\beta$-carotene at a concentration of $0.2 \mu \mathrm{M}$ augmented UVA-induced haem oxygenase- 1 induction indicating a pro-oxidant effect. The pro-oxidant effect of $\beta$-carotene was also demonstrated in rats that showed increased activity of phase I enzymes in liver, kidney and intestine as well as increased oxidative stress [18].

Lycopene is present in many fruits and vegetables, with tomatoes and processed tomato products being among the richest sources. Several recent studies suggest that dietary lycopene is able to reduce the risk of chronic diseases such as cancer and cardiovascular diseases. Although several mechanisms have been implicated in health-beneficial effects of lycopene, such as modulation of intercellular gap junction communication, hormones, immune system and metabolic pathways, the antioxidant properties of lycopene are thought to be primarily involved in its preventive effects in chronic diseases. Because of its high number of conjugated dienes, lycopene is one of the most potent antioxidants, with a singlet-oxygenquenching ability twice as high as that of $\beta$-carotene and 10 times higher than that of $\alpha$-tocopherol [21].

\section{Hydroxyl Radical Scavenging Activity}

Unlike superoxide, which can be detoxified by superoxide dismutase, the hydroxyl radical cannot be eliminated by an enzymatic reaction. Mechanisms for scavenging peroxyl radicals for the protection of cellular structures includes dietary antioxidants such as flavonoid and vitamin C [20, 21].

Radical hydroxly is the most reactive among all ROS. It has a single unpaired electron, thus, it can react with oxygen in triplet ground state. Radical hydroxyl interacts with all biological molecules and causes subsequent cellular damages such as lipid peroxidation, protein damage, and membrane destruction. Because cells have no enzymatic mechanism to eliminate radical hydroxyl, its excess production can eventually lead to cell death. The oxidation of organic substrates by radical hydroxyl may proceed by two possible reactions, either by addition of radical hyroxyl to organic molecules or due to abstraction of a hydrogen atom from it [17].

The hydroxyl radical scavenging activity of the various extracts was investigated in this study (table 2). All extracts almost have equal ability to scavenging the hydroxyl radical. Kuranji has the highest abilities to scavenging hydroxl radical than mentega fruit, timun suri and jackfruit.

\section{Chellating Effect of Ferrous Iron}

The ferrous ion chelating activities of mentega fruit, kuranji, pasak timun suri, and jackfruit extracts are shown in table 2. The metal scavenging effect of these samples decreased in the order of mentega fruit > kuranji $>$ timun suri $>$ jackfruit.

Although iron is vital for life, it can be toxic when it is present in excess. Iron homeostasis is a complex process, as there are many different proteins that respond not only to the total body burden of iron, but also to stimuli such as hypoxia, anemia and inflammation [22].

About $65 \%$ of iron is bound to hemoglobin, $10 \%$ is a constituent of myoglobin, cytochromes, and ironcontaining enzymes, and $25 \%$ is bound to the iron storage proteins, ferritin and hemosiderin. About $0.1 \%$ of body iron circulates in the plasma as an exchangeable pool, essentially all bound to transferrin. The process of chelation not only facilitates the transport of iron into cells, but also prevents ironmediated free radical toxicity [22].

The iron-mediated free radical toxicity leading to the formation of hydroxyl radicals and hydroperoxide decomposition reactions via Fenton reaction [23]. Fe2+ caused the production of oxyradicals and lipid peroxidation, therefore the ability of substances to chelating iron can be use as a valuable antioxidant. It was reported that the presence of chelating metal such as iron is capable of generating free radicals from peroxides and may be implicated in human cardiovascular disease $[1,23,24]$.

Many studies documented that mutations in superoxide dismutase enzymes and iron-uptake regulator may lead to excess levels of superoxide anion radicals and iron overload. Such a condition leads to the possibility of redox active iron to participate in organic and inorganic oxygen radical reactions, such as stimulating lipid peroxidation and catalyzing the 
formation of damaging hydroxyl radicals with subsequent tissue damage [22].

\section{Hydrogen Peroxide Scavenging Activity}

Hydrogen peroxide itself is not very reactive, but it can sometimes be toxic to cell because of it may increase the hydroxyl radical in the cells.

In mammalian cells, potential enzymatic sources of ROS include the mitochondrial electron transport chain, the arachidonic acid metabolizing enzymes lipoxygenase and cycloxygenase, the cytochrome P450s, xanthine oxidase, NADPH oxidases, uncoupled nitric oxide synthase, peroxidases, and other hemoproteins. These systems primarily catalyze one electron reduction of molecular oxygen to form radical superoxide which rapidly inactivates $\mathrm{NO}^{*}$ to form peroxynitrite. Under ambient conditions, some radical superoxide is dismutated to hydrogen peroxide spontaneously or catalyzed by superoxide dismutase. Of interest, loss of $\mathrm{NO}^{\circ}$ could lead to enhanced formation of hydrogen peroxide. Some enzymes, such as xanthine oxidase and glucose oxidase, can directly produce hydrogen peroxide by donating two electrons to oxygen. In the presence of heavy metals, hydrogen peroxide undergoes Fenton reaction to form highly reactive hydroxyl radical [24].

Thus removing $\mathrm{H}_{2} \mathrm{O}_{2}$ is very important throughout food systems. The composition of hydrogen peroxide into water may occur according to the antioxidant compounds as the antioxidant component present in the extract are good electron donors, they may accelerate the conversion of $\mathrm{H}_{2} \mathrm{O}_{2}$ to $\mathrm{H}_{2} \mathrm{O}$ [25-27].

The hydrogen peroxide scavenging activities of of mentega fruit, kuranji, pasak timun suri, and jackfruit extracts are shown in table 2.

Table 2 showed that the four selected fruits have a potential hydrogen peroxide scavenging activity. Timun suri has a higher scavenging activity and followed by mentega fruit, kuranji and jackfruit.

\section{CONCLUSIONS}

In present study the ascorbic acid, $\beta$-carotene, lycopene and antioxidant activity of four selected tropical fruits was evaluated. The levels of ascorbic acid decerased in the order of mentega fruit $>$ jackfruit $>$ timun suri $>$ kuranji. The levels of $\beta$-carotene and lycopene decreased in the order of mentega fruit > jackfruit $>$ kuranji $>$ timun suri. Mentega fruit have a highest chellating effect on ferrous iron followed by kuranji, timun suri and jackfruit. Kuranji have a highest hydroxyl radical scavenging activity and followed by mentega fruit, timun suri and jackfruit. For hydrogen peroxide scavenging activity, timun suri have a highest activity than mentega fruit, kuranji and jackfruit.

\section{REFERENCES}

1. Suhartono E, Viani E, Rahmadhan MA, Gultom IS, Rakhman MF, Indrawardhana D (2012) Total flavonoid and antioxidant activity of some selected medicinal plants in South Kalimantan of Indonesian. APCBEE Procedia. 4: 235-239.

2. Karadeniz F, Burdurlu HS, Koca N, Soyer Y (2005) Antioxidant activity of selected fruits and vegetables grown in Turkey. Turk J Agric For. 29: 297-303.

3. Nadeesha MKF, Bamunuarachchi, Edirisinghe EMRKBM, Weerasinghe WMSK (2007) Studies on antioxidant activity of Indian gooseberry and seed. J. Sci. Univ. Kelaniya. 3: 83-92.

4. Aris SRS, Mustafa S, Ahmat N, Jaafar FM (2009) Phenolic content and antioxidant activity of fruits of Ficus deltiodea var Angustifolia Sp. MJAS. 13: 146-150.

5. Lim YY, Lim TT, Tee JJ (2007) Antioxidant properties of several tropical fruits : A comparative study. Food Chemistry. 103: 1003-1008.

6. Soeksmanto A, Hapsari Y, Simanjuntak P (2007) Antioxidant content of parts Mahkota Dewa, Phaleria macrocarpa (Scheff) Boerl (Thymelaceae). Biodiversitas. 8: 92-95.

7. Gill SN, Sood S, Muthuraman A, Garg M, Kumar R, Bali M, Sharma PD (2010) Antioxidant, anti-inflammatory and analgesic potential of Cucumis sativus seed extract. Lat. Am. J. Pharm. 29: 927-932.

8. Agarwal M, Kumar A, Gupta R, Upadhyaya S (2012) Exctraction of polyphenol, flavonoid from Embica Officinalis, Citrus limon, Cucumis sativus and evaluation of their antioxidant activity. Orient. J. Chem. 28: 993-998.

9. Shanmugapriya K, Saravana PS, Payal H, Mohammed P, Binnie W (2011) Antioxidant activity, total phenolic and flavonoid content of Artocarpus heterophyllus and Manilkara zapota seeds and its reduction potential. Int J Pharm Pharm Sci. 3: 256-260.

10. Howlader SI, Rahman M (2012) Antioxidant and antidiarrhoeal Potentiality of Diosypros blancoi. Int. J. Pharmacol. 8: 403-409.

11. Chou HJ, Kuo JT, Lin ES.(2009) Comparative antioxidant properties of water extracts from different parts of beefsteak plant (Perilla frutescens). JFDA. 17: 489-96.

12. Ruch RJ, Cheng SJ and, Klaunig JE. (1989) Prevention of cytotoxicity and inhibition of intracellular communication by antioxidant catechins isolated from Chinese green tea. 
Carcinogenesis. 10: 1003-1008.

13. Cioroi M. (2007) Study on L-Ascorbic Acid Contetnts from Exotic Fruits. Cercetări Agronomice în Moldova Anul XXXX. 1: 23-27.

14. Phillips KM, Tarrago MT, Gebhardt SE, Exler J, Patterson KY, Haytowitz DB, Pehrsson PR, Holden JM (2010) Stability of vitamin $\mathrm{C}$ in frozen raw fruit and vegetable homogenates. Food. Comp. Anal. 23 : 253-259.

15. Rekha C, Poornima G, Manasa M, Abhipsa V, Devi JP, Kumar HTV, Kekuda TRP (2012) Ascorbic acid, total phenol content and antioxidant activity of fresh juices of four ripe and unripe citrus fruits. Chem Sci Trans. 1: 303310.

16. Iqbal K, Alam K, M. Muzaffar A.K.K (2004) Biological significance of ascorbic acid (vitamin C) in human health. Pak J Nutrition. 3: 5-13.

17. Sharma P, Ambuj BJ, Rama SD, M. Pessarakli. (2012) Reactive oxygen species, oxidative damage, and antioxidative defense mechanism in plants under stressful conditions. Journal of Botany. 1-26.

18. A.V. Rao, L.G. Rao. (2007) Carotenoids and human health. Pharmacological Research. 55 : 207-216.

19. Paolo P, Assunta C, Rosella S, Achille C (2012) Lycopene as a guardian of redox signalling. Acta Biochimica Polonica. 59: 21-25.

20. Chiosa V, Mandravel C, Kleinjans JCS, Moonen E (2005) Determination of $\beta$-carotene concentration in orange and apple juice and in vitamin supplemented drinks. Chimie Anul XIV (serie nouă). I-II : 253-258.
21. Batool F, Sabir SM, Rocha JBT, Shah HA, Saify ZS, Ahmed SD (2010) Evaluation of antioxidant and free radical scavenging activities of fruit exctract from Zanthoxyllum alatum : a commonly used spice from pakistan. Pak. J. Bot. 42: 4299-4311.

22. K. Jornova, M. Valko. (2011) Advances in metal-induced oxidative stress and human disease. Toxicology. 283: 6587.

23. Sudha G, Priya S, Shree RI, Vadivukkarasi S (2011) In vitro free radical scavenging activity of raw pepino fruit (Solanum muricatum aiton). Int J Curr Pharm Res. 3: 137 $-140$.

24. Elekofehinti OO, Kade IJ (2012) Aqueous extract of Solanum anguivi Lam. Fruits (African Egg Plant) inhibit $\mathrm{Fe} 2+$ and SNP induced lipid peroxidation in Rat's brain in vitro. Der Pharmacia Lettre. 4: 1352-1359.

25. Behyan O, Elmastas M, Gedikli F (2010) Total phenolic compounds antioxidant capacity of leaf, dry fruit and fresh fruit of feijoa (Acca sellowiana, Myrtaceae). J. Med. Plant. Res. 4: 1065-1072.

26. Pal R, Girhepunje K, Shrivastav N, Hussain MH, Thirumoorthy (2011) Antioxidant and free radical scavenging activity of ethanolic extract of Morinda citrifolia. Annals of Biological Research. 2: 127 - 131.

27. Suhartono E, Viani E, Rahmadhan MA, Gultom IS, Rakhman MF, Indrawardhana D (2012) Screening of medicinal plant for total flavonoid and antioxidant activity in South Kalimantan of Indonesian. IJCEA. 3: 297-299. 